\title{
The Impact of Halal Tourism Destination on Improving Community Prosperity
}

\author{
Gustina $^{1}$, Yenida ${ }^{2}$, Novadilastri ${ }^{3}$ \\ \{umikhazid@gmail.com¹,yenidase@gmail.com², novadilastri@ymail.com³ \\ Business Administration Department, Padang State Polytechnic, Indonesia ${ }^{1,2,3}$
}

\begin{abstract}
Tourism is a sector that is very crucial in increasing the country's foreign exchange. For Indonesia, it is very relevant since the natural and cultural riches that we have. This study aims to find out whether the positive impact obtained from halal tourism in Padang Beach on improving people's prosperity. This research is a qualitative study using interviews, observation and documentation as a method of collecting data. The collected data were analyzed with qualitative descriptive analysis. The results of this study indicate that the people around Padang Beach want to cooperate, participate and be involved in the management and development of Padang Beach tourism destinations with related parties such as the government (through city government and The city department of tourism and culture) and the private sector. They (in this case, local business people and the community) feel an increase in skills, increased employment opportunities, business chances for the local community. Directly, the existence of these tourist destinations increases the selling value of the goods / services they produce so that eventually an increase in economic and community prosperity.
\end{abstract}

Keywords: Halal Tourism, Padang Beach, Community Prosperity

\section{Introduction}

Tourism is a very fast-growing sector at this time. At the national level, the contribution of foreign exchange and employment in this sector is very significant .Even for 2019, which is still running, is estimated to have defeated foreign exchange earnings derived from CPO (palm oil) [1].

In terms of total revenue, foreign exchange from the tourism sector in 2016 amounted to US $\$ 13.568$ billion, which came in second place after CPO of US $\$ 15.965$ billion. In 2015, foreign exchange from the tourism sector was only US $\$ 12.225$ billion, or came in fourth place under Oil and Gas US \$ 18.574 billion, CPO US \$ 16.427 billion, and coal US \$ 14.717 billion. Seeing this foreign exchange increase is really very significant for the development of the Indonesian economy. According to World Bank data, an investment of US \$ 1 million can drive $170 \%$ of GDP (Gross Domestic Product). Following the facts, this is the highest follow-up impact of an Industry on its country, because the tourism industry is able to drive small and medium businesses (MSMEs) such as culinary, souvenirs, transportation and others [1]. 
The development of tourism is so fast and led to new names, such as sharia tourism which is now increasingly heard. This is supported by the development of Islamic economics which has become an important link at this time in the global economy. Since August 2016, Halal Tourism Indonesia, which previously used the term Sharia Tourism officially announced by the Ministry of Tourism. Indonesian Halal Tourism with the tagline "Halal Tourism Indonesia, The Halal Wonders", is a series of active efforts and the government's commitment to improve the image of Indonesia in all levels of the world's Muslim community. The concept of Indonesian Halal Tourism which is currently being intensively developed, is expected to be a media in building good perceptions about Indonesia and strengthening Indonesia's position in the international eyes [2].

Indonesia's vast territory, geographically very beautiful, and natural, has the potential to be developed so that it will be more attractive for both local and foreign tourists to explore it. Tourism in Indonesia consists of 2 forms, namely natural tourism and cultural tourism. Nature tourism covers all matters relating to the beauty and attractiveness of Indonesia's nature, be it exotic natural resources, rich nature with beautiful views and more. As for cultural tourism, we are rich in culture, customs, interesting and unique habits that have historical value. This is related to the beauty and heritage of the ancestors which is still maintained neatly, with the characteristics and cultural identities that are very original and unique. Both, natural tourism and cultural tourism have enormous potential to be developed in Indonesia, which of course will benefit us [3].

The purpose of this study is to explore the potential of halal tourism that will be able to improve the economy of the people around tourist objects / destinations. For this reason, this paper is structured in writing with an introduction, then the writing method, conducts discussions and discussions and provides conclusions as the closing.

\section{Literature Review}

Discussing tourism is indeed fun. Why not? We will become aware of news, enjoy or beautiful tourist attractions with positive influences that will bring benefits, such as feeling happy, comfortable, valuable experiences, relax and get happiness.

Referring UU No 10/2009 on tourism, tourism is a variety of tourism activities and is supported by various facilities and services provided by the community, business people, government and local governments. The tourist activity must have a tourist attraction, that is, everything that has a uniqueness, beauty and value in the form of diversity of natural wealth, culture and man-made products that are the target and destination of tourist visits. And Indonesia has all these attractions, so it's not surprising that the tourism sector is a sector that has the potential to generate income that will improve the economy of the community, especially in the area of tourism. As revealed by Dimyati, 2004, that the tourism industry is a very important industry, because it generates foreign exchange, raises trillions of rupiah transactions, creates jobs and encourages product growth. Therefore, this should be supported by all parties, especially those in direct contact with the sector [4]. 


\subsection{Halal Tourism in the World and Indonesia}

The growth of the Muslim population is very large in the world. As many as 1.8 billion (around $28 \%$ of the total world population) are spread across 148 countries, of which $62 \%$ are from the Asia Pacific (around 972 million people) [5]. Strengthened again, Muslim Millennial Travel Report 2017, said the growth of Muslim population is expected to grow 2 times faster than the world population (the number of Muslim population will rise $70 \%$, compared to the world population in general only 32\%) - from 1.8 billion in 2015 close to $3 \mathrm{M}$ in 2060. In terms of consumer spending, in 2015 the Islamic global economy reached an approach of up to US \$ 1.9 Trillion for food and lifestyle. Then this market will increase by around US \$ 3 trillion in 2021 (MMTR, 2017) [6].

One potential segment in this lifestyle is tourism. Halal tourism has started to be heard since 2015. Especially since it was introduced by the World Halal Travel Summit 2015, an event on tourism held by the Arab Tourism Office in Abu Dhabi, 20 Oct 2015, Indonesia has increasingly been recognized by the world as one of the halal tourist destinations that deserves to be taken into account because won several tourism events there. In principle, the implementation of Islamic tourism / halal tourism in Indonesia refers to the MUI Fatwa No. 108 / DSN-MUI / X / 2016, there are 2 general principles in organizing Islamic tourism / halal tourism, namely (1) avoiding polytheism, immorality, disobedience, tabdzir / israf, and harm, (2) creating benefit and benefit both materially and spiritually. While the provisions of Islamic tourist destinations according to the MUI, there are 3 provisions namely: [7].

1. Tourist destinations must be directed towards efforts to:

a. Realizing general benefit

b. Enlightenment, refreshment and reassurance

c. Maintain trust, safety and comfort

d. Realizing universal and inclusive good

e. Maintaining cleanliness, nature conservation, sanitation, and the environment

f. Respect socio-cultural values and local wisdom that does not violate the principles of sharia

2. Travel destinations must have:

a. Worship facilities that are suitable for use, easily accessible and meet shariah requirements.

b. Halal food and beverages guaranteed halal with MUI halal certificate

3. Tourist destinations must avoid:

a. Polytheism and Khurafat

b. Wickedness, adultery, pornography, porno-action, liquor, drugs and gambling

c. Performing arts and culture and attractions that are contrary to Islamic principles.

Thus the basis for the development of halal tourism in Indonesia, especially in West Sumatra, is very clear. Halal tourism focuses more on the concept of tourism by providing halal products, not only enjoyed by Muslim tourists. For non-Muslim tourists, halal tourism is one solution to get 
a pleasant entertainment experience for families while being safe from negative influences that are often found in places of entertainment / tourism [5].

In addition, Syofyan [8] added that besides providing safe and halal products, halal tourism provides a guarantee of equality for tourists, both Muslims and Non-Muslims who come, because this halal product is guaranteed to be healthy. Because the implementation of halal products in halal tourism contains "halal toyyiban" so as to get rid of things that are harmful to humans and the environment. Thus, halal tourism is not only beneficial for the tourism industry, but also for the community in increasing faith and preventing harm [8].

\subsection{Increasing Income of Community}

Basically, the government is always trying to make improvements to the people's economy through economic development. Economic development is an economic process that aims to increase the income per capita of the population or community in a country in the long run accompanied by fundamental changes in the economic structure and income distribution for residents of a country. Economic development will provide a change in society, both in terms of technology, community mindset, and institutional.

Economic development can be done by increasing community per capita [9] or increasing living standards by increasing community real income [10]. Indicators include (1) Real National Income,, (2) Real income per capita, (3) labor and unemployment, (4) public welfare, an increase in material welfare in the community can be seen from the distribution of goods and services, the smooth distribution of goods and services illustrates the distribution of income per capita in society [10].

\section{Research Methods}

\subsection{Data type}

This research is a qualitative research, using primary data (primary data) obtained through direct surveys in the field (field research) by researchers. Qualitative research is research that uses data that is not numerical, so in the analysis will use descriptive analysis qualitative Even if there are numbers, this is only to state the unit of number of things that are questioned / discussed in the interview.

\subsection{Data Collection Techniques}

Primary data were collected through in-depth interviews with several business operators and communities around Padang Beach, they have different types of businesses, such as food vendors (Pisang Kapik), beverage sellers, Langkitang and Pensi, as well as small / typical Padang food traders. They are included in MSMEs (Micro, Small and Medium Enterprises) which have been doing business around the Padang Beach for a long time. 


\subsection{Data analysis technique}

Data will be analyzed descriptively qualitatively so that it will enrich and sharpen the results of the discussion later. According to Greene, descriptive technique is a technique in analyzing data by describing or describing data that has been collected as it is. The results of the interview will be described so that the research object that has been studied becomes very clear [11].

\section{Results}

This study uses primary data through in-depth interviews as a method of collecting data. Interviews were conducted with several business actors and the community as informants who were around the Padang Beach destination using a structured questionnaire. The objective of this structured interview is so that the data obtained are more valid, unbiased, and clearly and precisely grouped. From here, this will make it easier for researchers to analyze and draw conclusions better. They include business people who have long been in contact with the world of tourism, especially for Padang Beach destinations. There were about 10 questions raised in this interview. The questions are as follows: (1) type of business, (2) monthly income, (3) opinion about the number of tourist visits and conflict involvement with visitors, (4) knowledge of halal tourism, (5) attitudes towards visitors, (6) ) involvement in the management of attractions, (7) involvement with efforts to protect / repair attractions, (8) community support, (9) provision of local economic enterprises in the tourism sector, (10) influence of tourist destinations on the economic level. From 10 big points questions, then this interview has expanded according to the factual found in the field, such as for community support extends to the form of initiative, participation in planning, cooperation and involvement with the developers and managers of tourism for the sustainability of the tour.

Data detecting through this interview began around the informant's profile. They are business people who have an age range of around 30-60 years, with varied educational backgrounds, elementary school graduates and high school graduates / equivalent. Their origin is from several places / areas that are close to Padang, such as Padang, Pariaman, Tiku and its surroundings. Has worked as a trader (businessman) in Padang Beach for about 8-10 years. Those from different previous occupational backgrounds, some who used to work as fishermen (but due to the hardships of challenges as sailors, decided to work in Padang Beach tourism destinations only), some used to be owners of breakfast stalls and some who had just graduated from school / graduated from high school then decided to migrate to Padang to become a businessman here.

At present the types of businesses they are involved in are traders (business people) around Padang Beach tourist destinations in the form of small and typical Padang food (Karupuak kuah and noddles), Langkitang and Pensi, and traders of Pisang Kapik and roasted corn. From the business, they claimed to be able to generate income in excess of Rp. 5 million / month, an income which is quite large at this time (above the regional UMR which only ranges from Rp. 2-2.5 Million / month). 
According to informants interviewed by the research team, in 2019, the number of visitors / tourists coming to Padang Beach has decreased. There are several things that cause this to apply, such as the current economic situation which is increasingly uncertain, vehicle / plane ticket prices are increasing and others. They saw a decrease in the number of visits from several important moments, such as during the Idul Fitri, and national holidays. Usually this time is the peak number of visits to Padang Beach, but for this year it looks rather decrease.

Even though this year's visit has decreased, when there are many visitors, they say that they have never been involved in any kind of conflict with visitors, because for those visitors who come are guests, they need to be served in order to get a positive experience. Opportunities for this conflict usually often occur when talking about prices, such as parking prices, prices of food sold, and prices of souvenir items. The tendency of informants to prefer peace.

Because this research focuses on the potential of the Padang Beach halal tourism, the following statement submitted by the researcher is an understanding of halal tourism. They (informants) claimed to have never heard of halal tourism. This shows that the lack of education and socialization carried out by parties related to them, but when explained the basic concepts about it, basically they agreed and were very supportive, they stated strongly agree if Padang Beach is managed to be one of the halal tourist destinations. Their statement shows the positive attitude of business people and the community towards the existence of this Padang Beach attraction.

The positive attitude of business actors and other communities found in this study is that there is a good, friendly and friendly reception towards the arrival of visitors to this destination location. They expressed their very well-received visitors here. This awareness is supported by an understanding that tourists who come are guests who must get good service, so that they get good experiences or impressions and are finally willing to come back to this destination.

In addition, another important thing found in this study is the involvement of business actors / local communities in the management of tourist objects and efforts to protect and improve the Padang Beach tourist destinations. Facilities and infrastructure provided by Padang Beach tourism managers (in this case the government through City Government and The city department of tourism and culture) are parking facilities, shops / kiosks, information centers, garbage bins, shelters / lodges, toilets, mushalla/ praying places, places to eat/ food corner, transportation facilities. It's very important in supporting the existence of this tourist destination into a comfortable and pleasant destination, so that their involvement (business actors / local communities) in management, protection and improvement will facilitate the government carry out its function as a manager who will then assist in making decisions and strategies for the sustainability of the existence Padang Beach tourist destination.

They strongly agreed and supported the sustainable management initiative for the Halal Tourism destination in Padang Beach. They also stated that they would participate in planning, expressed their strong agreement to collaborate and engage with related parties in the development and management of Padang Beach. This positive retention was born from their knowledge that the existence of this tourist destination is very important in supporting their lives. Without the existence of these destinations, business probabilities and opportunities to gain better income will 
be even smaller. For this reason, the sustainability of the halal tourism destination Padang Beach is very significant for them.

The real impact of the existence of this tourist destination on the community can be seen from the results of interviews and observations conducted by researchers. They are of the opinion that the existence of the Padang Beach tourism object has increased employment opportunities, business prospects for local residents and small entrepreneurs, increasing the skills of the local community related to tourism activities. This has directly increased the selling value of the goods / services they produce so that eventually there is an increase in the economic life in the household. They really get the benefits and positive impact of Padang Beach tourist destination. This shows that the presence of visitors / tourists provides economic benefits so that it can improve the welfare of the community.

\section{Discussion}

The following section will contain the results of the discussion regarding the extent to which Padang Beach tourist destinations can have a positive impact, especially economic impacts on the surrounding community.

From the results of interviews and observations conducted, it was found that positively the communities around Padang Beach, especially the business actors, were very receiving / feeling the impact. They feel that with the opening of these tourist destinations there is an increase in employment opportunities and increased living standards/ prosperity of them. This has led them to become a group that is eager to participate and assist in the management of this destination. They want to collaborate and be involved in development programs, and manage the sustainability of this tourist destination. These results are very linear with Fahmi's study which states that people who are aware of the importance of tourist destinations will participate in the management of these tourist destinations [12]. This is also supported by the results of Martadani and Slamet, who also confirmed that the community provides participation in tourist destinations that have a positive impact on them [13]

At present the community around the Padang Beach supports community-based management that promotes the concept of harmony between relevant stakeholders (government, private and community. This form of community-based tourism management is very effectively implemented with community involvement for the sustainability of the tourism. Communities and businesses around Padang Beach expects the government through the City Government and The city department of tourism and culture to involve them in the development programs of the Padang Beach tourism destination, with mutual discussion between the community and the government is to strengthen a program that is implemented. For that purposes, the government must issue one statement together to develop the community in order to protect nature sustainably as the main capital for improving the economy of the community for nature tourism such as Padang Beach.

The participation of the government to continue to open business chances and opportunities to improve the welfare of the community is also awaited by the community. They hope that the City Government and The city department of tourism and culture can provide better facilities so that there is a smooth flow for their businesses. One of the facilities they hope for is a permanent shop / place of business. 
With the supporting of all parties for the sustainability of the Padang Beach tourism (community, government, business people, and visitors), it is hoped that the sustainability of this destination will be better in the future, because of the awareness of all these parties to the importance of the existence of this destination to improve the economy of the community .

\section{Concluding Remarks}

Currently, tourism is a sector that is very powerful in increasing the country's foreign exchange. For Indonesia, it is very relevant to see the natural and cultural wealth that we have. The halal tourism ring that has been felt by Indonesia since winning a tourism event in the world, makes Indonesia increasingly attractive for tourists to visit. Therefore the development of this tourism potential must continue to be done so that it has a positive impact on many parties.

The results of this study indicate that the community is eager to participate and wants to be involved in the management and development of Padang beach tourism, because they (the community and surrounding businesses) are very aware of the importance of this destination in supporting their lives. The existence of these destinations has opened up job opportunities, business chances, improved their skills and ultimately contributed to the improvement of their standard of living and prosperity. For this reason, good cooperation between the community, business people and the government in realizing this comfortable and sustainable tourism destination is highly expected.

\section{Acknowledgements}

The research team would like to thank to the Padang State Polytechnic through the LP3M with the grants that have been given to complete this research.

\section{References}

[1] A. A. Chandra and D. Damarjati, "Tiga Tahun Jokowi-JK, Pariwisata Sumbang Devisa Terbesar Kedua," Detik Finance, 2017. [Online]. Available: https://finance.detik.com/berita-ekonomi-bisnis/d-3687715/tiga-tahun-jokowi-jkpariwisata-sumbang-devisa-terbesar-kedua.

[2] G. B. Widhasti, C. Damayanti, and H. S. Sardjono, "DIPLOMASI PUBLIK PEMERINTAH REPUBLIK INDONESIA MELALUI PARIWISATA HALAL," Solidaritas, vol. 2, no. 1, 2017.

[3] Boim B, "Desa Kuno yang Menjadi Desa Terindah Di Dunia ada di Sumatera Barat," 2017. [Online]. Available: https://www.goodnewsfromindonesia.id/2016/10/18/desakuno-yang menjadi-desa-terindah-di-dunia-ada-di-sumatra-barat.

[4] A. Dimyati, "Mendorong Perekonomian Dengan Pariwisata?," J. Din. Pembang., vol. 1, no. 1, pp. 17-22, 2004.

[5] N. Lisma, S. Yonaldi, and L. Zulbahri, "Factor-Faktor Yang Mempengaruhi Kunjungan Wisatawan Ke Objek Wisata Syariah Di Sumatra Barat," J. Manaj. Dan Kewirausahaan, vol. 8, no. 1, pp. pp1-15, 2016. 
[6] MMTR(Muslim Millenial Travel Report)- Halal Trip, "The Rising Wave Of Muslim Millennial Travelers Shaping A US\$100 Billion Market," 2017. [Online]. Available: https://www.halaltrip.com/halal-travel/muslim-millennial-travel-report//.

[7] Y. Rahma, Gustina, and Imelda, "Persepsi Nilai, Merek Dan Harga Bagi Konsumen Terhadap Wisata Syariah Di Pantai Padang," J. Ilm. Polibisnis, vol. 11, no. 1, pp. 38-54, 2019.

[8] R. Syofyan, Prospek Bisnis Pariwisata Syariah. Jakarta: Penerbit Republika, 2012.

[9] S. Sukirno, Pengantar Teori Makro Ekonomi. Jakarta: PT. Raja Grafindo, 1996.

[10] Irawan and Suparmoko, Ekonomi Pembangunan. Yogyakarta: PT.BPFE, 2002.

[11] J. C. Greene, Mixed Methods In Social Inquiry. San Francisco: Jossey-Bass, 2007.

[12] F. Muhammad, "Pesona Kearifan Lokal Sebagai Wahana Peningkatan Produktifitas Ekonomi Masyarakat," J. Pemberdaya. Masy. Media Pemikir. dan Dakwah Pembang., vol. 1, no. 2, pp. 301-320, 2018.

[13] N. Martadani and L. Slamet, "Model Pemberdayaan Potensi Lokal Dan Pengembangan Desa Wisata Brayut.” 2018. 